У технологї м'ясопродуктів перспективним напрямком досліджень є використання функціональних сумішей. Для удосконалення фаршевих систем варених ковбас використали розроблену $і$ досліджену функціональну харчову композицію, яка містить комплекс білкових препаратів з гідроколоїдами. Встановлено, що їі внесення до складу м'ясних фаршів покрашує та стабілізує їx функціонально-технологічні та структурно-механічні властивості. Отримані результати доводять перспективність заміни частини м'ясної сировини створеною композицією

Ключові слова: фарші варених ковбас, білоквмісна композиція, функціонально-технологічні властивості, ефективна в'язкість, граничне напруження зсуву

В технологии мясопродуктов перспективным направлением исследований является использование функциональных смесей. Для усовершенствования рецептурного состава фаршевых систем вареных колбас использовали разработанную и исследованную функциональную пищевую композицию, которая содержит комплекс белковых препаратов с гидроколлоидами. Установлено, ито ее внесение в состав мясных фарией улучиает и стабилизирует их функционально-технологические и структурно-механические свойства. Полученные результаты доказывают перспективность замены части мясного сырья созданной композицией

Ключевые слова: фарши вареных колбас, белоксодержащая композиция, функционально-технологические свойства, эффективная вязкость, предельное напряжение сдвига

\section{INFLUENCE OF FUNCTIONAL FOOD COMPOSITION ON THE PROPERTIES OF MEAT MINCE SYSTEMS}

I. Strashynskiy

PhD, Associate Professor* E-mail: sim2407@i.ua 0. Fursi k

Postgraduate Student* E-mail: oksana.fursik@mail.ru V. P a s i c h n i y Doctor of Technical Science, Professor*

E-mail: Pasww1@ukr.net A. Mary $\mathbf{n}$ in

$\mathrm{PhD}$, Associate Professor, Head of Laboratory Problem research laboratory**

E-mail: a_marinin@ukr.net

G. Gon charov PhD, Professor*

E-mail: GGI17@ukr.net

*Department of technology of meat and meat products**

**National University of Food Technologies Volodumurska str., 68, Kyiv, Ukraine, 01601

\section{Introduction}

Meat products comprise a significant share in the structure of nutrition of population of Ukraine. The priority direction of innovative activity of meat processing enterprises is the production of economically affordable products of consistent and high quality that are able to satisfy the low purchasing power of the population of Ukraine. Achievement of the set goal is possible if, while forming different mince systems, to introduce various food additives that are meant to replace a part of meat raw materials and improve its functional and technological properties (FTP) [1].

At present, about 2 thousand food additives are used in the food industry; they include substances for various purposes: colorants, flavorings, consistence stabilizers, preservatives, etc.

Additives gain special value in terms of modern manufacturing meat products due to a wide use of protein preparations, polysaccharides, etc. This makes it possible to specifically change the functional-technological characteristics of the food system and receive the necessary technological effect and essentially influence the color, taste and aroma of the produce.

Under conditions of constant growth of prices for food additives, Ukrainian producers are interested in making an objective choice of trading forms and doses of their introduction in order to minimize the costs of production of meat products and to stabilize their quality, and, consequently, to enhance the technological substantiation of using food additives [2].

The relevant area of research is substantiation of expedience of using the developed protein containing functional food composition, which contains rationally selected mix of protein preparations, hydrocolloids with structure forming nanocomposit (food additive E551) and defining its influence on properties of mince systems of cooked sausages.

\section{Literature analysis and problem statement}

Mince systems of cooked sausages are a complex poly-dispersed system of coagulation type that consists mostly of protein, fat and water. The moisture, introduced during mince preparing process, binding with protein, forms a water-protein basis that contains water- and salt-soluble proteins, as well as solutions of salts, sugars, phosphates, etc. This complex water-protein matrix is a continuous dispersed medium, in which dispersed finely ground particles of fat, muscle and connective tissue form the so-called "emulsion" [3].

The basic requirement for obtaining a high-quality product in the technology of cooked sausages is the provision of dispersed state of moisture, protein and fat in the mince throughout the entire process of manufacturing. In this regard, it is necessary to correctly select food additives that allow providing for high quality emulsion. 
The main of them are the structure-forming polysaccharide structures (xanthane gum, guar gum, carob tree gum, gum-arabic etc.), protein preparations of vegetable and animal origins [4-6].

In the meat products technology, protein preparations play a role of connective and structure-forming substance, at the same time replacing the meat part. Due to this, the strong ties between the proteins of meat raw material and the introduced proteins are formed at subsequent thermal treatment. This allows manufacturing products of a stable structure and provides for a high quality.

An introduction of protein preparations of animal origin on the basis of connective tissue instead of the meat raw materials (5-30\%) can increase the index of moisture binding capacity (MBC) up to $100 \%$, lead to the improvement of structural-mechanical properties (SMP), as it is evidenced by results of research into boundary shear stress [7, 8]. The use of milk protein affects the emulgation ability of mince, helps to reduce the possibility of formation of bouillon-fat swells in the finished product $[8,9]$. Along with the milk proteins, soy protein products play an important role in shaping the FTP of mince systems. The use of $3-10 \%$ of soy isolate in the composition of meat mince increases the penetration rate and decreases boundary shear stress. Thus, the use of soy isolate in technology of sausages from low-grade beef allows decreasing toughness and increasing the juiciness of sausages [10].

A considerable number of studies are devoted to studying the polysaccharide structure. Thus, the rational level of introducing kappa-carrageenan to sausages with low fat content, which makes $0.245-1.5 \mathrm{~g}$ per $100 \mathrm{~g}$, iota-carrageenan to composition of cutlet beef in amount of $0.410 \mathrm{~g}$ per $100 \mathrm{~g}$ makes it possible to stabilize meat emulsion, improve the MBC and provides for a high quality of products. These results are related to the formation of stable complexes in the interaction of carrageenan with muscle proteins when heated, and the existence of negatively charged groups as a part of carrageenan, which interact with the free water, added to the mince system [11].

Scientists found that the introduction of kappa-carrageenan to meat mince partially reduces the rate of MBC (on average by $2 \%$ ) and improves rheological properties, such as boundary shear stress (by $24 \%$ ). However, the use of combination of carrageenan with guar gum in the same formulas of sausage produce increases the indicators of MBC and boundary shear stress by $3 \%$ and $20 \%$ respectively as compared with the control sample. This shows that using complexes based on carrageenan allows a compensation for the shortage of gel-formers of the protein nature [5, 12].

Individual use of food additives increases and complicates the labor consumption of the technological process. Analysis of research [13] demonstrates the benefits of using complex additives in the form of ready-made mixes. This increases the production efficiency and simplifies the technological process, provides for a consistent quality of the final product, helps to achieve the desired technological effect and to provide for the necessary MBC, SMP and organoleptic properties of finished products.

It was found that the use in formulations of sausage produce of hydrocolloid mixes (guar gum, xanthane gum, carob tree gum, conjuac in various ratios increases the rate of adhesive-cohesive work by $27-68 \%$ and lowers boundary sheer stress on average by $9 \%$, provides thickening and stabilization of the structure, due to which mince systems effectively retain moisture [13].
Adding a mix of kappa- and iota-carrageenan in the ratio of $2: 1$ in the amount of up to $0.8 \mathrm{~g}$ per $100 \mathrm{~g}$ and dairy proteins in the amount of up to $0.2 \mathrm{~g}$ per $100 \mathrm{~g}$ in the form of emulsion to the composition of sausages can reduce losses during thermal treatment and to improve the stability of the emulsion. This is due to the fact that the carrageenan interacts with protein polar groups and integrates them into their own gel systems, improving the functional-technological properties of meat minces. Optimization of the following indicators [14] shows that the addition of $0.35 \mathrm{~g} / 100 \mathrm{~g}$ of milk protein, $0.593 \mathrm{~g} / 100 \mathrm{~g}$ of mix of kappa- and iota-carrageenan and 5 grams of fat provides the highest values of the basic properties of meat mince systems.

It was proved that the combination of kappa- and lambda-carrageenans reduces losses at boiling and improves moisture retaining and emulgation capacity of meat systems and enhances the structural-mechanical properties of the finished product.

Most scientific papers are aimed at studying the basic properties of two-component systems and their impact on the product quality. It is known that existence of various substances (proteins, hydrocolloids, salts of organic and inorganic acids, etc.) even in minor concentrations significantly modifies the functional properties of these systems, which greatly affects the quality of finished products [2, 4, 7-10]. Thus, the prediction of the technological effect of an additive introduction to a food product creates the need for studying the complex multicomponent systems (for example, combining hydrocolloids with protein preparations) and studying their impact on the quality of meat products as opposed to two- and three-component ones.

The need for preservation of the qualitative indicators of mince systems and products under conditions of unstable composition and properties of the raw material, which supplied for processing, makes relevant the task of creating functional complex food compositions (the integrated use of protein preparations with different stabilizers and emulgators) for improving the quality of mince and finished products. This allows, on the one hand, reducing the cost of manufactured products, and on the other, improving chemical-technological, rheological and organoleptic characteristics.

At the Department of Technology of Meat and Meat Products at National University of Food Technologies (Ukraine), the formulations of protein-containing functional food composition (FFC) were developed and researched. Their composition includes protein preparations of vegetable and animal origin, xanthane gum, guar gum, carboxymethylcellulose, and carrageenan.

The obtained results of the research indicate that the active acidity of $10 \%$ water suspension of FFC is within 6.8-7.8 units. The MBC of the selected hydrated mix makes $95-85 \%$, depending on degree of hydration, which is by $5-10 \%$ higher in comparison with other samples. The use of silica (food additive E551, nanocomposite with dimensions of particles of $5.88 \mathrm{~nm}[15,16])$ in the amount of $0.3 \%$ makes it possible to improve the MBC of the hydrated composition on average by $3-4 \%$. The selected sample is characterized by the best indicators [17]. The introduction of silica improves not only the basic properties of protein properties of created compositions, but also positively influences muscle proteins of the mince of cooked sausages [18]. High functional properties of the resulting composition and the ability of silica, which is included in their composition to improve them, as 
well as the positive experience of other scientists in the field of using complex mixtures, makes it possible to argue about the possibility of improving the functional-technological and structural-mechanical properties of meat mince systems and providing consistent quality of finished products.

\section{Aim and tasks of research}

The aim of present research is to create meat mince systems with the replacement of basic raw materials with the developed protein containing FFC.

To achieve the set aim, the following tasks were to be solved:

- to prove the relevance of introducing the devised compositions to the formulation of mince systems;

- to develop model formulations of cooked sausages with the replacement of basic raw materials for the developed protein containing FFC;

- to explore the impact of FFC on FTP of mince systems (stability of emulsion, moisture binding and emulgation abilities);

- examine the effect of introducing FFC on the structural-mechanical indicators of model minces (effective viscosity and boundary shear stress);

- establish a rational amount of replacement of meat raw materials with the developed FFC with preservation of sustainable quality of meat mince emulsions.

\section{Materials and methods of studying FTP and SMP of mince systems of cooked sausages using functional food composition}

For the solution of the problems, in the technology of cooked sausages we used hydrated protein containing FCC, which included: protein of pork skins Belkoton - C95 - $35 \%$, soy isolate Pro Vo $500 \mathrm{U}-15 \%$, guar gum $-20 \%$, xanthane gum $-8 \%$, the carboxymethylcellulose $-15 \%$, dry milk whey $-7 \%$, pyrogenic silica $-0.3 \%$. To the composition we introduced Silica, synthesized by the specialists of the Department of Amorphous Structures and Structurally Organized Oxides of the Institute named after A. A. Chuiko of the NAS of Ukraine (Ukraine), with specific surface area $232 \mathrm{~m}^{2} / \mathrm{g}$, with respective mean radius of primary nanoparticles of $5.88 \mathrm{~nm}$ and bulk density $\rho_{0} \approx 22 \mathrm{~g} / \mathrm{cm}^{3}$ $[15,16]$. Protein of animal origin from the pork skin Belkoton C-95 of the enterprise-producer "Scanflavour", country: Denmark. Soy isolate Pro Vo 500U, produced by Group of Companies "Protein. Technology. Ingredients", Russia. Dry milk whey, produced by Tulchin creamery, Ukraine. The country of origin of carboxymethylcellulose, xanthane gum is Finland, enterprise CP Kelco, guar gum was produced by "Sarda Gums\&Chemicals", India.

The formulation of cooked sausages (first grade, TC U 15.1-20021369-005:2007) was selected as the control sample; it includes second grade beef, pork semi-fat, poultry meat (red chicken meat), salted pork fat (thoracic), flour, blend, salt and spices. On its basis we developed the formulas of the studied samples of cooked sausages, in which we replaced meat raw material with the correspondent amount of hydrated FFC (20,30 and $40 \%)$.

An important aspect of determining the feasibility of replacing meat raw material in the technology of cooked sau- sages with the protein containing FFC is determining of the basic indices that define the FTP and SMP of the obtained minces. The detailed description of the methods of exploring FTP and SMP of the mince systems of cooked sausages with the use of the functional food composition is given in [19].

\section{Results of research into the influence of protein containing functional food composition on basic properties of mince systems of cooked sausages}

To characterize the ability of the obtained cooked sausage minces to retain moisture, we determined the indicators of $\mathrm{MBC}_{\mathrm{a}}$ (content of bound moisture in \% to the total moisture in the product) and $\mathrm{MBC}_{\mathrm{m}}$ (content of bound moisture in $\%$ to mass of weighed portion of the product) that are listed in Fig. 1.

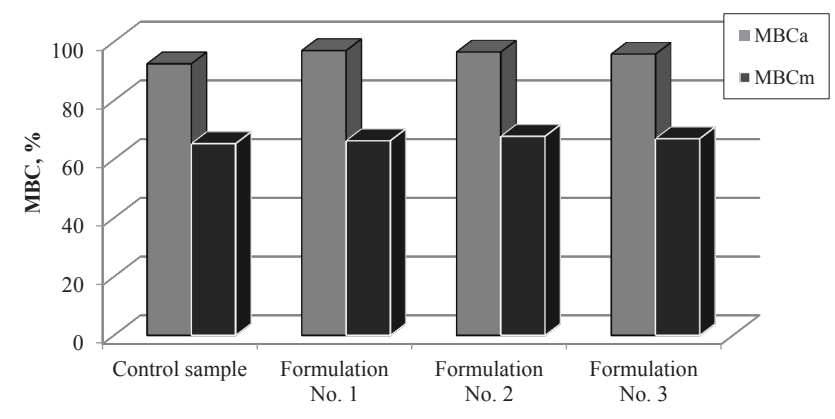

Fig. 1. Dependence of indicators $\mathrm{MBC}_{\mathrm{a}}$ and $\mathrm{MBC}_{\mathrm{m}}$ on the formulation of mince for cooked sausages

The moisture content in the control sample is $64.2 \pm 2.0 \%$, in the experimental samples we observed the increase in this indicator. In particular, for formulation No. 1 it makes $72.3 \pm 2.2 \%$ for formulation No. $2-73.3 \pm 2.1 \%$, for formulation No. $3-75 \pm 2.4 \%$. This is due to the larger moisture content of hydrated FFC, in which 20 parts of water fall for 1 part of the composition, which increases this indicator in comparison with meat raw materials.

Magnitude $\mathrm{pH}$ of the control mince sample is $5.65 \pm$ $\pm 0,2$ units, we observed the shift of this indicator to the alkaline side: for formulation No. 1 it was $5.8 \pm 0.21$; for formulation No. 2 it was $5.95 \pm 0.19$; for formulation No. 3 it made $6.3 \pm 0.2$. An increase in this indicator with an increase in the amount of the FCC is explained by the value of magnitude of $\mathrm{pH}$ of hydrated functional food composition, which ranges within $6.2-7.2$.

The introduction of the FFC to the composition of mince of cooked sausages increases the MBC of the sample, made by formulation No. 1 by $4.9 \%$ in comparison with a control sample, of the sample, made by formulation No. 2 - by $4.8 \%$, of the sample, made by formulation No. 3 - by $3.6 \%$. One can note a partial decrease in this indicator with an increase in the replacement of meat raw material with the FFC. This is explained by a somewhat lower indicator for the MBC for hydrated FFC, which makes $85.7 \pm 3.4 \%$ at the degree of hydration of 1:20. Plasticity for the control sample is $24.5 \pm 1.1 \mathrm{~cm}^{2} / \mathrm{g}$; for the sample, made according to formulation No. $1-27.6 \pm 1.0 \mathrm{~cm}^{2} / \mathrm{g}$; according to formulation No. 2 - 29.0 $\pm 1.15 \mathrm{~cm}^{2} / \mathrm{g}$; according to formulation No. 3 $38.5 \pm 1.5 \mathrm{~cm}^{2} / \mathrm{g}$. These data indicate that with an increase in replacement of meat raw material, the mince plasticity increases, so its elasticity and fluidity also increase. 
To determine the characteristics of the experimental minces to absorb and retain fats in their composition, the indicators of emulgation ability and the stability of the emulsion were explored. The data are shown in Fig. 2, 3.

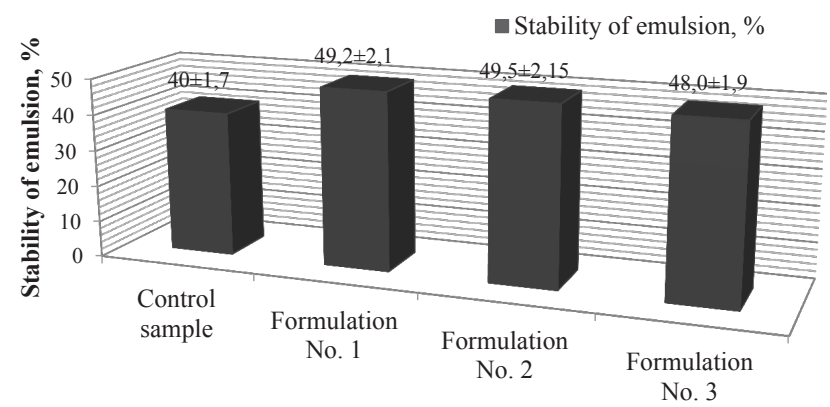

Fig. 2. Change in stability of emulsion depending on the formulation composition of mince for cooked sausages

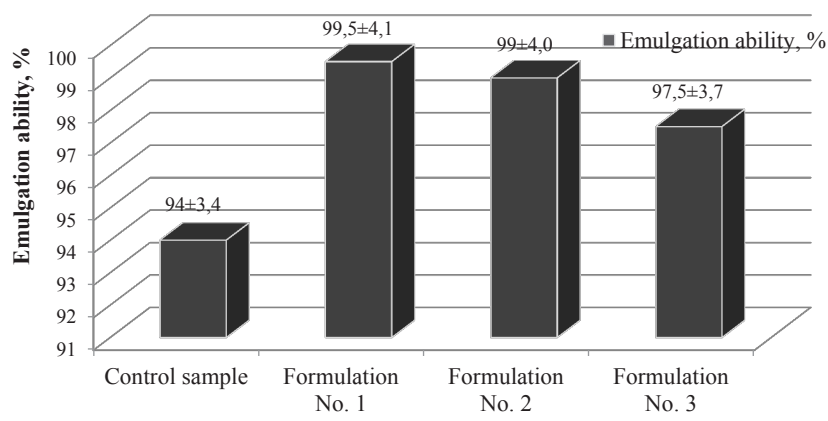

Fig. 3. Change in emulgation ability depending on the formulation composition of mince for cooked sausages

The stability of emulsion for the experimental meat minces ranges within $48-49.5 \%$ and proves the benefits of using the FFC in formulations of cooked sausages. In model minces, this indicator increases by $22.5 \%$ in comparison with the control sample. Emulsion ability comprises $94-99.5 \%$ and increases as compared with the control sample for formulation No. 1 and № 2 by $5.8 \%$, for formulation No. 3 by $3.7 \%$.

The consistence of mince samples depends directly on the content of moisture, fat, degree of grinding and is characterized by the magnitude of boundary shear stress. Compared with the change in magnitudes of other rheological properties, boundary shear stress is most sensitive to changes in technological and mechanical factors, so this indicator is used to assess the mince in the process of its production $[1,9]$.

Dependence of effective viscosity of mince on shear stress rate is the main characteristic of the SMP of mince systems because effective viscosity is a summary characteristic that describes the equilibrium state between processes of recovery and destruction of the mince structure. So, the next step was to study the structural and mechanical properties of mince and to compare them with the control sample to determine the influence of the created compositions on consistence. Indicators of boundary shear stress and effective viscosity for minces of cooked sausages are shown in Fig. 4, 5.

Exploration of the SMP indicates that with an increase in amount of the introduced composition, the effective viscosity of meat mince decreases. In particular, for the experimental sample of formulation No.1 it decreased by $19.5 \%$, for formulation No. 2 - by $55.4 \%$, for formulation No. 3 - by $70.7 \%$ compared with the control sample. Along with this, there is a decrease in the indicator of boundary shear stress by $19.5 \%, 41.6 \%$, and $60.4 \%$, respectively. This is explained by an increase in amount of dispersed medium, which determines elasticity and fluidity of the experimental minces compared with the control sample. Application of the FFC modifies the SMP and improves the consistence, since an increase in effective viscosity contributes to getting more tender and juicy product.

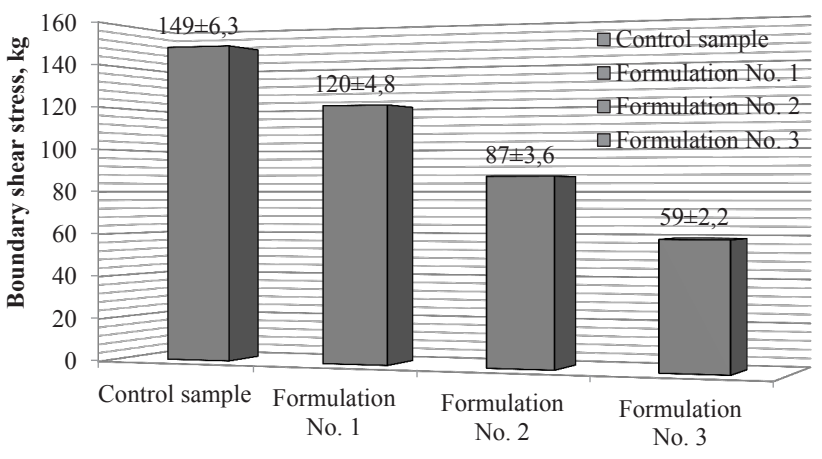

Fig. 4. Study of the boundary shear stress in mince for cooked sausages

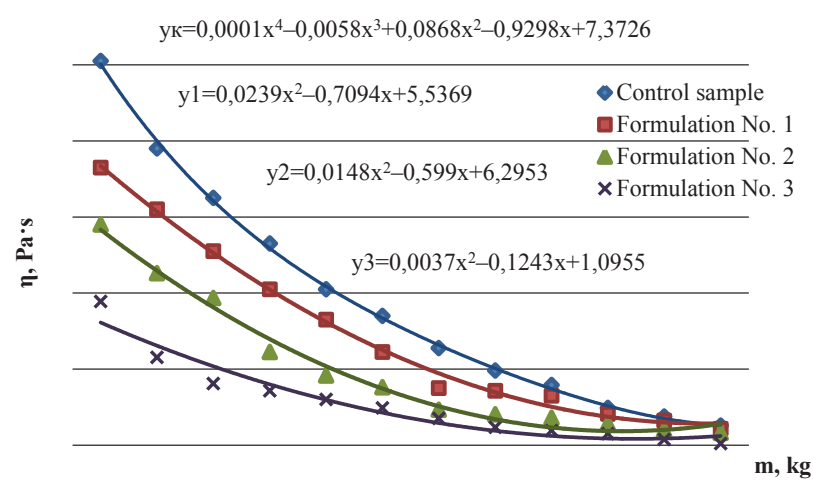

Fig. 5. Dependence of effective viscosity on the formulation composition of mince for cooked sausages

\section{Discussion of results of studying the influence of protein containing functional food composition on basic properties of the obtained mince systems for cooked sausages}

A major role in determining the FTP of mince systems is played by proteins. The replacement of meat proteins with the hydrated protein containing FFC partially decreases the indicator of the MBC of the studied mince samples compared with the control sample. This is due to its high degree of hydration. However, the components, which are included in the composition formulation were selected taking into account the possibility of synergy interactions between them, which made it possible for it, along with meat proteins, to bind and retain not only the water introduced with hydration, but also additional moisture according to the formulation ratio.

The study of the stability of emulsion and emulgation ability of minces of cooked sausages proves the expedience of using the FFC. These indicators in all experimental samples increase compared with the control indicators. High FTP of the studied minces is substantiated by the properties of the ingredients that make the composition. Thus, protein preparations have high indicators of moisture binding ability and 
due to the hydrophilic groups contribute to the formation of mince systems with immobilized moisture in its composition. Hydrophobic groups, that make up the protein molecule, at the stage of mince preparation encapsulate the lipid faction, form the protein-structured shell around it and provide for the stability of mince systems in the technological process. Authors of paper [8] share this opinion and underline that proteins on the basis of collagen containing raw materials have a high ability to swell and retain moisture, which is explained by the structure of the molecule, which provides the stabilization of the system fat-water end prevents fat fraction from separating in technological process.

Selected mixes of high molecular substances (hydrocolloids) are characterized by high moisture absorbing and moisture retaining ability and provide for consistently high properties of meat mince systems. The authors [5] believe that it may be influenced by the microstructure of derivatives of cellulose (carboxymethylcellulose), which is an extensive capillary system, as well as the ability of their fibers to aggregate with the formation of the reinforced grid, which stabilizes the meat system and prevents the release of moisture and fat. In addition, gums are soluble only in the aqueous phase, and have hydrophilic groups, which are more or less evenly distributed along the entire length of a molecule. Due to their dissolution, this provides an increase in viscosity and density that makes the movement of fat balls difficult and prevents the formation and merging of fat globules and lamination of meat emulsion. These processes result into the creation of a structure similar to meat, which is especially important in manufacturing of emulgated products, in particular, cooked sausages.

The study of boundary shear stress and effective viscosity of meat minces allowed giving quantitative assessment to the key SMP, choose the optimal technological processes of manufacturing and forecast in advance the properties of the finished product.

For most mince systems, coefficient of viscosity that characterizes the resistance to layers moving relative to one another and decreases with an increase in shear stress or in the rate of shear stress (applied force). This is due to the fact that minces are, as a rule, the structured systems, i. e., the systems that have a certain macro- and microstructure, in which all the components are arranged relative to each other and are interconnected. The obtained indicators of effective viscosity are explained by the resistance of the components to the influence of the applied force (i. e. quick recovery of broken bonds between components). Food hydrocolloids, having the properties of thickeners and stabilizers, are able to restore the bonds between themselves and increase the viscosity and density of the mince system. This happen due to the branched structure of molecules with existing hydrophilic groups and intensified interaction between dispersed particles due to appearance of the synergy effect during combining in the mince composition. Protein preparations of vegetable and animal origin also perform structural functions in food products. Thanks to their ability for gel formation and interaction with meat proteins they form thick gel structures with built-in molecules of hydrocolloids, providing for the quality of products corresponding to the data, presented in papers [1,7-11].

Combining meat ingredients with each other and with mixes of food additives changes the mince structure, which is influenced by protein content, its fractional composition, etc. Depending on the properties of additives, the water and fat content changes, which leads to the modification of SMP of resulting product. Thus, the introduction of the FFFC with a high degree of hydration (1:20) into the composition of minces part increases the moisture content, which led to a decrease in indicator of boundary shear stress in the researched samples of meats mince for cooked sausages. This is due to an increase in thickness of the water-salt layer between dispersed pieces of beef. It is influenced by the selected components of the mix (hydrocolloids and protein preparations), with high indexes of moisture binding and moisture retaining ability. Significant fat content contributes to the displacement of moisture in the layer between the mince particles, which only increases the distance between them and decreases boundary shear stress. However, protein preparations possess high FTP and SMP, which allowed retaining these components, along with hydrocolloids, in the matrix and provide for the stability of mince systems.

The addition of silica (food additive E551) to the FFC composition increases the FTP of the experimental samples and contributes to structure formation in mince systems due to the interaction with protein preparations and meat protein, which corresponds to the results, presented in papers [17, 18, 20, 21].

Rational combination of food additives in the mix composition, taking into account the potential synergy interactions made it possible to obtain a sustainable meat system matrix with encapsulated formulation components and improve the FTP and SMP of minces of cooked sausage products.

At this stage, the studies of the influence of the developed protein containing FFC on the quality of finished cooked products are being carried out.

\section{Conclusions}

1. The expedience of using protein preparations and hydrocolloids in the form of complex mixes in the technology of emulgated meat products was substantiated. The rational ratio of these additives for the developed functional composition with high functional-technological and structuralmechanical properties was experimentally determined. It was found, that the introduction of food additive E551 (silica) improves the basic properties of the composition due to the interaction with protein preparations.

2. On the basis of theoretical and practical recommendations, the model formulation s of cooked sausages, in which meat raw material was replaced with the correspondent amount of hydrated FFC (20, 30 and $40 \%)$, was developed.

3 . It is proved that the replacement of meat raw material with the developed protein containing FFC in the amount of $20-40 \%$ (in hydrated form) increases the MBC of the mince of model samples by $3.5-5 \%$. In addition, the ability of meat emulsion to absorb and retain fat in a gel structure improved, in particular, the stability of emulsion increased by $22.5 \%$ and emulgation ability increased by $5 \%$ compared with the control sample.

4. An improvement of SMP of the meat systems due to the influence of the developed compositions was revealed, namely the effective viscosity decreased by $19.5-70.7 \%$ compared with the control sample, indicator of boundary shear stress decreased by $19.5-60.4 \%$. 
5. In the process of studying functional-technological and structural-mechanical properties of model mince samples, we established the rational amount of substitution of meat raw materials by introducing functional composition in the amount of up to $30 \%$ in the hydrated form.

Therefore, the following data indicate that the developed composition improves the FTP and SMP for minces of cooked sausages and provides for the production of high and consis- tent quality. However, it is impossible without research to establish the influence of this mix on such important indicators as biological value and digestibility of the finished products.

To prove finally the expedience of replacing meat raw materials with the developed composition and its positive influence on properties of meat products, the next stage of work involves determining a complex of indicators of the finished sausage products.

\section{References}

1. Lisitsyin, A. B. Osnovnyie printsipyi sovershenstvovaniya assortimenta i stabilizatsii kachestva kolbasnyih izdeliy [Text] / A. B. Lisitsyin, I. M. Chernuha, A. A. Semenova, V. A. Aleksahina // Vse o myase. - 2006. - Vol. 1. - P. 4-7.

2. Semenova, A. A. O tehnologicheskoy praktike primeneniya pischevyih dobavok v myasnoy promyishlennosti [Text] / A. A. Semenova // Vse o myase. - 2009. - Vol. 1. - P. 17-24.

3. Rogov, I. A. Biotehnologiya myasa i myasoproduktov [Text] / I. A. Rogov, A. I. Zharinov, L. A. Tekuteva, T. A. Shepel. - Moscow: DeLi print, 2009. - 296 p.

4. Hollingworth, C. S. Hydrocolloids - How to choose? [Text] / C. S. Hollingworth // Brenntag Food \& Nutrition Europe. - 2011.Vol. 1. - P. 2-9.

5. Williams, P. A. Introduction to food hydrocolloids [Text] / P. A. Williams, G. O. Phillips. - Handbook of hydrocolloids. Second edition, 2009. - P. 1-22. doi: 10.1533/9781845695873.1

6. Pasichniy, V. Structure stabilization of fermented-milk pastes [Text] / V. Pasichniy, N. Yushchenko, I. Mykoliv, U. Kuzmyk // Ukrainian Food Journal. - 2015. - Vol. 4, Issue 3. - P. 431-439.

7. Ryizhinkova, I. V. Sovremennyie belkovyie preparatyi zhivotnogo proishozhdeniya v tehnologii emulgirovannyih myasoproduktov [Text] / I. V. Ryizhinkova, S. I. Postnikov // Myasnaya industriya. - 2009. - Vol. 1. - P. 43-45.

8. Prabhu, G. A. Utilization of pork collagen protein in emulsified and whole muscle meat products [Text] / G. A. Prabhu, D. R. Doerscher, D. H. Hull // Journal of Food Science. - 2004. - Vol. 69, Issue 5. - P. 388-392. doi: 10.1111/j.1365-2621.2004. tb10703.x

9. Atughonu, A. G. Thermo-rheology, quality characteristics and microstructure of frankfurters prepared with selected plant and milk additives [Text] / A. G. Atughonu, J. F. Zayas, T. J. Herald, L. H. Herbers // Journal of Food Quality. - 1998. - Vol. 21, Issue 3. P. 223-238. doi: 10.1111/j.1745-4557.1998.tb00518.x

10. Krishtafovich, V. I. Vliyanie soevyih izolyatov na kachestvo farshevyih myasnyih produktov [Electronic resource]/V. I. Krishtafovich, T. G. Kuznetsov. - Available at: http://www.meatbranch.com/publ/view/309.html

11. Ayadi, M. A. Influence of carrageenan addition on turkey meat sausages properties [Text] / M. A. Ayadi, A. Kechaou, I. Makni, H. Attia // Journal of Food Engineering. - 2009. - Vol. 93, Issue 3. - P. 278-283. doi: 10.1016/j.jfoodeng.2009.01.033

12. Hodyirev, A. A. Sravnitelnaya otsenka FTS kommercheskih preparatov karraginanov dlya myasnoy promyishlennosti [Text] / A. A. Hodyirev, D. B. Svetlakov // Pischa. Ekologiya. Chelovek, 2003. - 58 p.

13. Mansvetova, E. V. Pischevyie polisaharidyi i ih ispolzovanie v myasnoy promyishlennosti [Text] / E. V. Mansvetova // Myasnaya industriya. - 2008. - Vol. 12. - P. 25-29.

14. Marchetti, L. Low-fat meat sausage with fish oil: Optimization of milk proteins and carrageenan contents using response surface methodology [Text] / L. Marchetti, S. C. Andres, A. N. Califano // Meat Science. - 2014. - Vol. 96, Issue 3. - P. 1297-1303. doi: $10.1016 /$ j.meatsci.2013.11.004

15. Market Attitude Research Services, Australian Community Attitudes about Nanotechnology - 2005-2009 [Text]. - Department of Industry, Innovation, Science and Research, Australia, 2009.

16. International Risk Governance Council, Policy Brief: Appropriate Risk Governance Strategies for Nanotechnology Applications in Food and Cosmetics [Text]. - Geneva, Siwtzerland, 2009.

17. Pasichniy, V. M. Development of combined protein-fat emulsions for sausage and semifinished products with poultry meat [Text] / V. M. Pasichniy, A. I. Marynin, O. O. Moroz, A. M. Heredchuk // Eastern-European Journal of Enterprise Technologies. - 2015. Vol. 1, Issue 6 (73). - P. 32-38. doi: 10.15587/1729-4061.2015.36232

18. Ivanov, S. Polufabrikatyi iz myasa indeyki s ispolzovaniem teksturoformiruyuschih napolniteley [Text] / S. Ivanov, V. Pasichniy, I. Strashinskiy, A. Marinin, O. Fursik, V. Krepak // Himiya i tehnologiya pischi. Nauchnyie trudyi. - 2014. - Vol. 2, Issue 48. P. 25-33.

19. Strashynskiy, I. The study of properties of minces in boiled sausages with functional food composition use [Text] / I. Strashynskiy, O. Fursik, V. Pasichniy, A. Marynin, G. Goncharov // EUREKA: Life Sciences. - 2016. - Vol. 6. - P. 31-36. doi: 10.21303/25045695.2016 .00238

20. Pasichnyi, V. M. Investigation of the emulsions based on functional food compositions containing protein [Text] / V. M. Pasichnyi, I. M. Strashynskyi, O. P. Fursik // Technology Audit and Production Reserves. - 2015. - Vol. 3, Issue 3 (23). - P. 51-55. doi: $10.15587 / 2312-8372.2015 .44177$

21. Strashynskyi, I. M. Reolohichni vlastyvosti hidratovanykh bilokvmisnykh funktsionalnykh kharchovykh kompozytsii [Text] / I. M. Strashynskyi, V. M. Pasichnyi, O. P. Fursik // Visnyk NTU «KhPI». Seriia: Novi rishennia v suchasnykh tekhnolohiiakh. 2015. - Vol. 62, Issue 1171. - P. 166-170. 